\title{
Familial aggregation and heritability of markers of metabolic risk, physical activity, and physical fitness in nuclear families from Muzambinho (Minas Gerais, Brazil)
}

João Paulo dos Anjos Souza Barbosa', Luciano Basso', Teresa Bartholomeu', Januária Andrea Souza Rezende ${ }^{3}$, Jorge Alberto de Oliveira ${ }^{2}$, António Prista ${ }^{4}$, Go Tani², José António Ribeiro Maia ${ }^{5}$, Cláudia Lúcia de Moraes Forjaz'

\begin{abstract}
Objective: This study investigated the familial aggregation and heritability of markers of metabolic risk, physical activity, and physical fitness in nuclear families from Muzambinho (Minas Gerais, Brazil). Subjects and methods: The study included members of 139 families, comprising 97 fathers (aged $40 \pm 7$ years), 129 mothers ( $35 \pm 6$ years), 136 sons (12 \pm 4 years), and 121 daughters (12 \pm 5 years). Evaluated markers included (A) body mass index, waist circumference, glycemia, and cholesterolemia, as metabolic risk markers; (B) total weekly volume of physical activity, as a physical activity marker; and $(\mathrm{C})$ relative muscle strength, as a physical fitness marker. Correlations between family members and heritability $\left(\mathrm{h}^{2}\right)$ were estimated using the software S.A.G.E. Results: Significant familial correlations were obtained between parents-offspring for glycemia and cholesterolemia (both $\rho=0.21, p<0.05)$ and relative muscle strength $(\rho=0.23, p<0.05)$, and between siblings for waist circumference, glycemia, total weekly volume of physical activity, and relative muscle strength ( $\rho$ variation 0.25 to $0.36, p<0.05$ ). Heritability values were significant for almost all variables ( $\mathrm{h}^{2}$ variations: $20 \%$ to $57 \%$ for metabolic risk markers, $22 \%$ for the total weekly volume of physical activity, and $50 \%$ for relative muscle strength), except for waist circumference ( $h^{2}=15 \%, p=0.059$ ). Conclusion: The presence of significant correlations between family members and/or significant heritability strengthens the possible genetic and/or common familial environment influence on metabolic risk markers, total weekly volume of physical activity, and relative muscle strength. Arch Endocrinol Metab. 2019;63(3):215-21
\end{abstract}

Keywords

Cardiovascular risk factors; motor activity; muscle strength; families; genetic epidemiology

\author{
${ }^{1}$ Laboratório de Hemodinâmica \\ da Atividade Motora, \\ Escola de Educação Física \\ e Esporte, Universidade de \\ São Paulo, SP, Brasil \\ ${ }^{2}$ Laboratório de Comportamento \\ Motor, Escola de Educação \\ Física e Esporte, \\ Universidade de São \\ Paulo, SP, Brasil \\ ${ }^{3}$ Instituto Federal do Sul de \\ Minas - Campus Muzambinho, \\ Muzambinho, MG, Brasil \\ ${ }^{4}$ Núcleo de Investigação em \\ Actividade Física e Saúde, \\ Centro de Investigação e \\ Desenvolvimento do Desporto \\ e Actividade Física (CIDAF), \\ Faculdade de Educação Física e \\ Desporto (FEFD), Universidade \\ Pedagógica, Maputo, Moçambique \\ ${ }^{5}$ Laboratório de Cineantropometria \\ e Gabinete de Estatística Aplicada, \\ Centro de Investigação, Formação, \\ Intervenção e Inovação em \\ Desporto (CIFI2D), Faculdade \\ de Desporto, Universidade \\ do Porto, Porto, Portugal
}

Correspondence to:

João Paulo dos Anjos Souza Barbosa Rua Coronel Ferreira Leal, 246, ap. 1 05588-090 - São Paulo, SP, Brasil jpdosanjos@usp.br

Received on Dec/12/2017 Accepted on Mar/11/2019

DOI: $10.20945 / 2359-3997000000137$

\section{INTRODUCTION}

$\mathrm{C}$ ardiovascular diseases are the main cause of death worldwide (1) and in Brazil (2). Several factors, like the presence of metabolic disease (e.g., obesity, diabetes, and dyslipidemia), are known to increase cardiovascular risk (1). On the other hand, regular practice of physical activity is considered a cardiovascular protective factor. Physical fitness also has cardiovascular protective effects (3), and body strength has been recently shown to be inversely related to cardiovascular morbidity and mortality (4). Since all these factors may be affected by genetic and environmental influences, it is important to identify the magnitude of the contribution of each influence (genetic and environmental) to understand how different interventions may affect an individual's cardiovascular risk.

Genetic epidemiology is a research area focused on the investigation of possible genetic influences on a trait $(5,6)$. The first two steps of a genetic epidemiology study are the identification of significant familial aggregation (greater correlations of a trait within family members than expected by chance) and heritability 
(proportion of a trait variability in a population that may be explained by genetic factors) of the trait, which are assumptions necessary to ensure the presence of genetic influence $(6,7)$. However, familial aggregation and heritability vary among different populations, since environmental influences differ with location and time, reducing or increasing the genetic influence (6-8). Familial aggregation and heritability of a trait have a specific value for each population; therefore, these characteristics must be studied in different contexts because the replication of significant values reinforces the genetic involvement in determining a specific trait.

Familial aggregations of markers of metabolic risk, physical activity, and physical fitness have been investigated outside Brazil. Studies from France, United States, and Portugal have found greater correlations between biological relatives (parents-offspring and siblings) than between father-mother for body mass index (BMI) (9), glycemia (10), and metabolic syndrome index (11), supporting a genetic influence on these traits. Regarding total physical activity, familial aggregation between genetically related relatives varies from an absence of correlation (12) to significant correlations $(\mathrm{r}=0.34)$, as found in a study by Maia and cols. (13). For physical fitness, studies of familial aggregation are limited to aerobic fitness $(14,15)$.

Similarly, the heritability of markers of metabolic risk, physical activity, and physical fitness has been studied in different countries and in a single study conducted in Brazil. As expected, heritability varies substantially in different populations. Systematic reviews have shown that heritability of BMI ranges from $30 \%$ to $76 \%$ (8). In the Brazilian study mentioned above, the heritability of metabolic risk markers varied from $29 \%$ to $51 \%$ (16). Regarding total physical activity, heritability varies from $10 \%$ to $30 \%$ (17) and was $35 \%$ in the Brazilian study (18). To the best of our knowledge, the heritability of muscle strength has not been investigated in Brazilian nuclear families.

Based on the exposed above, the study of familial aggregation and heritability is important to ensure the genetic influence in different contexts. It is also important to study these aspects in Brazil, where only a single study in this area has been performed to date. Thus, the objectives of this study were to investigate the familial aggregation and heritability of markers of metabolic risk (BMI, waist circumference, glycemia, and cholesterolemia), physical activity (weekly volume of total physical activity), and physical fitness (relative muscle strength) in nuclear families from the municipality of Muzambinho (Minas Gerais, Brazil). Our hypothesis was that all markers of metabolic risk, physical activity, and physical fitness would present significant familial aggregation and heritability.

\section{SUBJECTS AND METHODS}

A sample of families was recruited among 10-year-old students participating in a large study about growth, maturation, and motor development in Muzambinho, (19). Data regarding blood pressure heritability from this study have already been published (20).

The study was approved by the Ethics Committee of the School of Physical Education and Sport at the University of São Paulo (Brazil), and written informed consent was obtained from all participants.

Data were collected between March 2008 and November 2009 in Muzambinho, a small city in the state of Minas Gerais, Brazil. At the time of data collection, the population of Muzambinho was 19,925 and included 5,650 residents aged 5 to 19 years. The municipality has a human developmental index of 0.801 , and its main economy is based on agriculture, livestock, and handicrafts (21). The school system, at the time of data collection, consisted of 13 schools ( 2 private and 11 public schools, including 3 state and 8 municipal ones) with 2,996 school-age children enrolled (321 in the private schools, 1,845 in the state schools, and 830 in the municipal schools) (21). The city had 11 healthcare facilities at data collection. The number of deaths related to cardiovascular diseases was 35 in 2008 and 37 in 2009, representing $28 \%$ and $31 \%$, respectively, of the deaths in the municipality each year (22).

The study investigators visited the selected families at their homes to explain the study's procedures, obtain written consent for participation in the study, and schedule a new visit to the home the next morning. In this second visit, fasting blood samples were collected from all family members, and a third appointment was set for an evening visit at one of the city's schools. In this third appointment, anthropometric measurements, physical activity habits, and physical fitness were assessed.

\section{Measurements}

Weight $(\mathrm{kg})$ and height $(\mathrm{m})$ were measured with an electronic scale (Filizola, São Paulo, Brazil) following standard procedures, and the BMI was calculated as weight $(\mathrm{kg}) /$ height $(\mathrm{m})^{2}$. Waist circumference was 
measured at the level of the umbilicus $(23,24)$. Based on BMI values, the participants were classified as normal, overweight, or obese according to international guidelines $(24,25)$. International tables were used to classify the participants' waist circumference $(23,24)$.

Glycemia and cholesterolemia were measured using automatic devices (Accu-Chek, Roche, São Paulo, Brazil; and Accutrend GC, Roche Diagnostics, Mannheim, Germany, respectively) after at least 6 hours of fasting $(26,27)$.

Physical activity was assessed by a specific and culturally appropriate structured interview conducted with all family members together. The main questions included the family's usual commuting physical activity (how they commute from one place to another in the city, if walking, cycling, etc.), occupational physical activity (what they do for work, if domestic chores, rural tasks, deliveries, etc.), and leisure time physical activity (what they do during leisure time, if cycling, soccer, swimming, gym classes, ballet, or physical play/games such as tag, hide-and-seek, hopscotch, skip rope, and others). In addition, children were asked about their physical activity at school (including physical education classes and physical activity during breaks). When the participant declared to perform physical activity in any of the mentioned domains (commuting, occupational, school, and/or leisure time), the weekly frequency and duration of the activity were questioned, and the weekly volume of the activity was calculated as the product of frequency and duration. The weekly volume of total physical activity ( $\mathrm{min} /$ week) was obtained by the unweighted sum of the volumes of all physical activities performed.

Muscle strength was assessed by the isometric handgrip test using a hydraulic hand dynamometer (SH 5001, Saehan Corporation, Masan, South Korea). After adjustment of the handle of the equipment to the size of the volunteer's hand, each volunteer performed a handgrip movement using the maximum strength possible with the dominant hand, and the value obtained was recorded (28). This value was relativized by body weight, yielding the relative muscle strength.

\section{Statistical analysis}

Initial exploratory and descriptive analyses were performed using SPSS 20.0 (SPSS Inc., Chicago, IL, USA). Two-way analysis of variance (ANOVA) was used to compare traits between generations and sexes. The chi-square test was used to compare categorical variables between family groups. The description of the nuclear families was obtained with PEDSTATS (29). Analysis of missing values was carried out using SYSTAT 13 (Systat Software, Inc., San Jose, CA, USA) within each family structure, and missing data distribution was carried out at random. Correlations of each marker between family members were calculated using regression residuals after adjustment for the covariates age, sex, age $\mathrm{X}$ sex, $\operatorname{age}^{2}$, and $\operatorname{age}^{2} \mathrm{X}$ sex, as suggested by Bouchard and cols. (30). Correlations between parent-offspring $\left(\rho_{\mathrm{PO}}\right)$, siblings $\left(\rho_{\mathrm{SI}}\right)$, and father-mother $\left(\rho_{\mathrm{FM}}\right)$ were calculated using the software S.A.G.E. (3l). Heritability $\left(\mathrm{h}^{2}\right)$ was also estimated with S.A.G.E. (31) using Student's $t$ distribution for robust estimation of the parameters. This analysis was preceded by adjustments for the covariates age, sex, age $\mathrm{X}$ sex, $\operatorname{age}^{2}, \operatorname{age}^{2} \mathrm{X}$ sex.

The level of significance was set at $5 \%$ for all analyses.

\section{RESULTS}

In all, 210 families were invited to participate in the study. Data were effectively obtained from 139 families ranging in size from 3 to 9 members, with most families having 3 or 4 members $(81 \%)$.

In some families, the mother and (particularly) the father were absent in the evaluation. Thus, the final sample consisted of 97 fathers, 129 mothers, and 257 children (136 sons and 121 daughters). The age of the offspring ranged from 6 to 24 years (sons 12 \pm 4 years; daughters $12 \pm 5$ years), and the parents' age ranged from 24 to 65 years (fathers $40 \pm 7$ years; mothers $35 \pm 6$ years). Concerning the socioeconomic status of the participants, only $10.8 \%$ of the families had at least one of the parents with an occupational activity requiring a university degree. Regarding family health history, $51.1 \%$ of the families reported a history of cardiovascular disease.

As expected, BMI and waist circumference values were significantly higher in parents compared with offspring, but were comparable between sexes within the same generation (Table 1). When the BMI was analyzed as a categorical parameter, the frequency of excess weight (overweight and obesity) was similar between men and women of the same generation, and higher in the first generation (fathers $[59.5 \%]=$ mothers $[50.0 \%]>$ sons $[22.0 \%]=$ daughters $[20.0 \%], \mathrm{p}<0.05)$. The frequency of altered waist circumference was lower 
in fathers $(9.5 \%)$ compared with all other family groups and was greater in mothers $(44.2 \%)$ compared with sons $(24.6 \%)$ and daughters $(31.9 \%)$, who presented similar frequencies of altered waist circumference. Glycemia was significantly higher in fathers compared with sons and mothers, while cholesterolemia was higher in both parents compared with offspring and in fathers compared with mothers (Table 1).

The weekly volume of total physical activity was higher in parents compared with offspring and was similar between sexes at both generations. The relative muscle strength was higher in the first versus second generation and greater in males than females (father > mother $>$ sons $>$ daughters).
Table 2 presents the results of familial correlations. In regard to metabolic risk markers, there was no significant correlation between family members in terms of BMI. However, significant correlations were observed in terms of waist circumference between siblings $(\rho=0.25)$, glycemia between all family pairs (parents-offspring, $\rho=0.2 \mathrm{l}$; siblings, $\rho=0.28$; and father-mother, $\rho=0.36$ ), and cholesterolemia between parents-offspring $(\rho=$ $0.21)$. Regarding the physical activity marker, the weekly volume of total physical activity correlated significantly between siblings $(\rho=0.36)$ and father-mother $(\rho=0.42)$. The physical fitness markers, relative muscle strength, correlated significantly between parents-offspring $(\rho=0.23)$ and siblings $(\rho=0.35)$.

Table 1. Descriptive information on markers of metabolic risk, physical activity, and physical fitness among family members from Muzambinho (MG, Brazil)

\begin{tabular}{|c|c|c|c|c|}
\hline & Fathers Mean \pm SE (n) & Mothers Mean \pm SE $(n)$ & Sons Mean \pm SE $(n)$ & Daughters Mean \pm SE (n) \\
\hline \multicolumn{5}{|l|}{ Metabolic risk markers } \\
\hline BMI $\left(\mathrm{kg} / \mathrm{m}^{2}\right)$ & $\begin{array}{c}25.8 \pm 0.36 \\
(\mathbf{n}=\mathbf{8 4})\end{array}$ & $\begin{array}{c}25.6 \pm 0.41 \\
(\mathbf{n}=\mathbf{1 2 0})\end{array}$ & $\begin{array}{c}18.4 \pm 0.31^{*} \\
(\mathbf{n}=\mathbf{1 2 7})\end{array}$ & $\begin{array}{c}18.8 \pm 0.39^{*} \\
(\mathbf{n}=\mathbf{1 1 5})\end{array}$ \\
\hline WC (cm) & $\begin{array}{c}91 \pm 0.98 \\
(\mathbf{n}=\mathbf{8 4})\end{array}$ & $\begin{array}{l}87 \pm 1.00 \\
(\mathbf{n}=\mathbf{1 2 0})\end{array}$ & $\begin{array}{c}66 \pm 0.97^{*} \\
(\mathbf{n}=\mathbf{1 2 7})\end{array}$ & $\begin{array}{c}67 \pm 1.11^{*} \\
(\mathbf{n}=\mathbf{1 1 5})\end{array}$ \\
\hline Glycemia (mg/dL) & $\begin{array}{c}96 \pm 1.25 \\
(\mathbf{n}=\mathbf{9 2})\end{array}$ & $\begin{array}{c}89 \pm 0.89^{\#} \\
(\mathbf{n}=\mathbf{1 2 5})\end{array}$ & $\begin{array}{c}86 \pm 0.77^{\star} \\
(\mathbf{n}=\mathbf{1 3 4})\end{array}$ & $\begin{array}{l}84 \pm 0.73 \\
(\mathbf{n}=\mathbf{1 1 9})\end{array}$ \\
\hline Cholesterolemia (mg/dL) & $\begin{array}{c}192 \pm 3.67 \\
(\mathbf{n}=\mathbf{7 1})\end{array}$ & $\begin{array}{c}177 \pm 2.30^{\#} \\
(\mathbf{n}=\mathbf{9 1})\end{array}$ & $\begin{array}{c}163 \pm 1.88^{*} \\
(\mathbf{n}=\mathbf{7 2})\end{array}$ & $\begin{array}{c}170 \pm 2.75^{\star} \\
(\mathbf{n}=\mathbf{6 4})\end{array}$ \\
\hline \multicolumn{5}{|l|}{ Physical activity marker } \\
\hline WVTPA (min/week) & $\begin{array}{c}2018 \pm 99.44 \\
(\mathbf{n}=\mathbf{8 3})\end{array}$ & $\begin{array}{c}2044 \pm 94.05 \\
(\mathbf{n}=\mathbf{1 1 9})\end{array}$ & $\begin{array}{c}1320 \pm 85.70^{*} \\
(\mathbf{n}=\mathbf{1 2 6})\end{array}$ & $\begin{array}{c}1030 \pm 70.30^{*} \\
(\mathbf{n}=\mathbf{1 0 9})\end{array}$ \\
\hline \multicolumn{5}{|l|}{ Physical fitness marker } \\
\hline Relative strength (kg) & $\begin{array}{c}0.59 \pm 0.01 \\
(\mathbf{n}=\mathbf{8 3})\end{array}$ & $\begin{array}{c}0.46 \pm 0.01 \# \\
(\mathbf{n}=\mathbf{1 2 0})\end{array}$ & $\begin{array}{c}0.55 \pm 0.01^{*} \\
(\mathbf{n}=\mathbf{1 2 3})\end{array}$ & $\begin{array}{c}0.47 \pm 0.01^{\text {} \#} \\
(\mathbf{n}=\mathbf{1 0 9})\end{array}$ \\
\hline
\end{tabular}

SE: standard error; BMl: body mass index; WC: waist circumference; WVTPA: weekly volume of total physical activity. ${ }^{*} p<0.05$ compared with first-generation family member of same sex. \# $p<0.05$ compared with males of the same generation.

Table 2. Correlations between different pairs of family members regarding markers of metabolic risk, physical activity, and physical fitness in nuclear families from Muzambinho (MG, Brazil)

\begin{tabular}{|c|c|c|c|c|c|c|}
\hline Variables & $\rho_{\mathrm{P} 0} \pm \mathrm{SE}$ & n pairs & $\rho_{\mathrm{SI}} \pm \mathbf{S E}$ & n pairs & $\rho_{\mathrm{FM}} \pm \mathrm{SE}$ & n pairs \\
\hline \multicolumn{7}{|l|}{ Metabolic risk markers } \\
\hline BMI $\left(\mathrm{kg} / \mathrm{m}^{2}\right)$ & $0.03 \pm 0.06$ & 343 & $0.17 \pm 0.11$ & 109 & $0.03 \pm 0.12$ & 65 \\
\hline WC (cm) & $0.01 \pm 0.06$ & 343 & $0.25 \pm 0.09^{\dagger}$ & 109 & $0.15 \pm 0.12$ & 65 \\
\hline Glycemia (mg/dL) & $0.21 \pm 0.07^{\dagger}$ & 379 & $0.28 \pm 0.09^{\dagger}$ & 135 & $0.36 \pm 0.09^{\dagger}$ & 78 \\
\hline Cholesterolemia (mg/dL) & $0.21 \pm 0.09^{\dagger}$ & 170 & $0.14 \pm 0.16$ & 39 & $-0.15 \pm 0.14$ & 46 \\
\hline \multicolumn{7}{|l|}{ Physical activity marker } \\
\hline WVTPA (min/week) & $0.10 \pm 0.07$ & 331 & $0.36 \pm 0.09^{\dagger}$ & 104 & $0.42 \pm 0.10^{\dagger}$ & 66 \\
\hline \multicolumn{7}{|l|}{ Physical fitness marker } \\
\hline Relative strength (kg) & $0.23 \pm 0.06^{\dagger}$ & 337 & $0.35 \pm 0.11^{\dagger}$ & 107 & $0.16 \pm 0.12$ & 61 \\
\hline
\end{tabular}

BMl: body mass index; WC: waist circumference; WVTPA: weekly volume of total physical activity; $\rho_{\mathrm{PO}}$ : parents-offspring correlation; $\rho_{\mathrm{SI}}$ : siblings correlation; $\rho_{\mathrm{FM}}$ : father-mother correlation. $+p<0.05$. 
Heritability values for markers of metabolic risk, physical activity, and physical fitness were all significant, except for waist circumference, for which a trend toward significance was detected (Table 3 ). Heritability for metabolic markers ranged from $15 \%$ for waist circumference (not significant, $\mathrm{p}=0.059$ ) to $57 \%$ for cholesterolemia. The heritability value was $22 \%$ for the weekly volume of total physical activity and $50 \%$ for the relative muscle strength.

Table 3. Maximal heritability ( $\mathrm{h} 2 \pm \mathrm{SE}$ ) of markers of metabolic risk, physical activity, and physical fitness in nuclear families from Muzambinho (MG, Brazil)

\begin{tabular}{lcc}
\hline Variables & $\mathbf{h}^{2} \pm \mathbf{S E}$ & $\mathbf{p}$ value \\
\hline Metabolic risk markers & & \\
$\mathrm{BMI}\left(\mathrm{kg} / \mathrm{m}^{2}\right)$ & $0.20 \pm 0.09$ & 0.019 \\
WC $(\mathrm{cm})$ & $0.15 \pm 0.09$ & 0.059 \\
Glycemia (mg/dL) & $0.38 \pm 0.08$ & $<0.001$ \\
Cholesterolemia (mg/dL) & $0.57 \pm 0.11$ & $<0.001$ \\
Physical activity marker & & \\
WVTPA (min/week) & $0.22 \pm 0.08$ & $<0.001$ \\
Physical fitness marker & & \\
Relative strength (kg) & $0.50 \pm 0.09$ & $<0.001$ \\
\hline
\end{tabular}

SE: standard error; BMl: body mass index; WC: waist circumference; SBP: systolic blood pressure; DBP: diastolic blood pressure; WVTPA: weekly volume of total physical activity.

\section{DISCUSSION}

The main findings of the present study are: (A) metabolic risk markers, except for BMI, present significant correlations between pairs of genetically linked family members. All metabolic risk markers but waist circumference presented low to moderately significant heritability; (B) weekly volume of total physical activity showed significant familial aggregation between siblings and father-mother, as well as significant low heritability; and $(\mathrm{C})$ relative muscle strength presented significant familial aggregation between parents-offspring and siblings, as well as moderate significant heritability.

The understanding of the concepts of familial aggregation and heritability is important for the interpretation of studies involving these two concepts. The presence of significant correlations between family members suggests a genetic and/or environmental influence shared by family members (common environment) on the trait (32). When correlations are significant between genetically linked pairs (parents- offspring and siblings), a genetic influence is possible, whereas in significant correlations observed only between nongenetically linked relatives (father-mother), a common environmental influence is more likely. When heritability is estimated in nuclear families, as done in the present study, separation of genetic and common environmental influences is unfeasible; thus, what is estimated is the maximal genetic influence supposing there is no effect from the common environment (32).

In general, significant familial correlations and/ or heritability are observed for all metabolic risk markers, suggesting an influence of genes and/or common environmental on these traits $(9,11)$ and corroborating the generally accepted idea that genes and familial environment partially determine an individual's metabolic risk (33). However, considering the obesity markers assessed in our study, BMI showed no familial correlation and low heritability, while waist circumference only presented a significant correlation between siblings and a trend toward significant heritability. Although genetic and common environment may have had a role in determining the obesity risk in this population, their influence was weak. Heritability values of obesity markers vary considerably in the literature, ranging from $30 \%$ to $76 \%$ in different reviews $(8,34)$, but the results found in the present study (20\% for BMI and $15 \%$ for waist circumference) are below the limits reported previously. An important determinant of obesity is an individual's eating habit, which is greatly influenced by cultural traditions (8). However, the eating habits of different families in small cities like Muzambinho are probably very similar, which explains the lower heritability observed in such populations. Unfortunately, the eating habits of the participants in this study were not evaluated and should be included in future studies.

Regarding other metabolic risk markers, correlations for glycemia were significant for all family pairs, with the highest value observed between fathermother, who share no genes, suggesting an important influence of common environment on this trait (35). The heritability value of glycemia $(38 \%)$ was significant and similar to the one found in another Brazilian study conducted in Baependi (33\%) and to the highest value reported in the literature (39\%) (16). Cholesterolemia showed a significant correlation among parentssiblings and a moderate heritability $(57 \%)$, which was higher than both the value reported in the Baependi study $(29 \%)$ and the highest value reported in the 
literature (51\%) (36). Discrepancies in cholesterolemia heritability between Baependi and Muzambinho may be explained, at least in part, by different sampling strategies. The Baependi study involved many family generations, while the present study involved nuclear families with school-age offspring, who likely share the family environment more frequently among themselves than with distant family members like cousins, uncles, and grandparents. Together, these results suggest that a common environment may have a great influence on cholesterolemia. Based on previous discussion, it is possible to propose that interventions on unique environments and family common environments are more prone to have positive results in reducing obesity and other metabolic markers, respectively.

Weekly volume of total physical activity presented significant correlations between siblings $(r=0.36)$ and father-mother $(r=0.42)$, and a significant but low heritability of $22 \%$. As significant correlations were observed between both genetically and nongenetically related relatives, and were higher between the nongenetically related pairs, these results suggest that a common environment may influence this trait (32). The fact that the correlations were identified for pairs within the same generation (siblings and father-mother) suggests a special influence of the common environment shared by members of each generation in determining the weekly volume of physical activity (37). The low heritability value found for this trait is within the range reported in a review (6-62\%) (38) and similar to the values found by Chaves and cols. (24\%) (39), but lower than those reported in the Baependi study (35\%) (18). This low heritability suggests that unique environments may have an important influence in determining this trait. Considering together the results from the familial aggregation and heritability, interventions aiming to increase the weekly volume of physical activity in this population should focus in the common environment shared by relatives from the same generation and the extra-familial environment.

To the best of our knowledge, this is the first study to investigate the familial aggregation and heritability of relative muscle strength in Brazilian nuclear families. Relative muscle strength had a significant correlation between parents-offspring and siblings and a moderate heritability $\left(h^{2}=0.50\right)$. These results suggest that half of the variation of relative muscle strength in Muzambinho's population might be explained by genetic factors and/or a common familial environment.
This result is aligned and within the range of isometric strength shown in other international studies involving nuclear families, showing estimates of heritability involving this type of strength of $27 \%$ to $58 \%$ (40).

Despite the importance of these findings, this study has some limitations. The sample derived from a population with high levels of weekly total physical activity. Also, due to the selection criteria (families of 10-year-old children), the sample consisted of families with young adults as parents. These features may reduce the chance of metabolic risk abnormalities and increase the influence of the common familial environment. Since we had no previous knowledge of the physical activity patterns of this population at the time of data collection, we applied a structured open interview $(20,41)$. However, interviews are vulnerable to some degree of inaccuracy; thus future studies should implement measures that are more objective. The size of the cohort of the present study may be considered insufficiently large, but is similar to that of previous studies $(19,20,41)$ and represented $2.2 \%$ of the population of Muzambinho.

In conclusion, in families from Muzambinho, markers of metabolic risk, weekly volume of total physical activity, and manual strength showed significant familial aggregation and/or heritability, suggesting a genetic and common environmental influence on these traits.

Acknowledgments: we would like to acknowledge the volunteers, heads of the schools, and the Education and Health Secretariats of Muzambinho. We would also like to thank the students, teachers, and informatics technicians who helped with the data collection and analysis. The research was supported by multiple agency grants: CNPq (\#478249/2007-1), USP, and CAPES-PROEX (001).

Each author contributed individually and significantly to the development of this study. JPASB, AP, GT, JARM, and CLMF designed the study. LB, TB, AP, JASR, JAO, and CLMF collected the data. JPASB, TB, JASR, AP, LB, JAO, JARM, and CLMF tabulated and analyzed the data. All authors participated actively in the discussion of the results. JPASB, JARM, and CLMF were the main contributors in the manuscript preparation. All authors approved the final version of the manuscript.

Disclosure: no potential conflict of interest relevant to this article was reported.

\section{REFERENCES}

1. Cannon CP. Cardiovascular disease and modifiable cardiometabolic risk factors. Clin Cornerstone. 2007;8(3):11-28.

2. Ministério da Saúde. Cadernos de informações de saúde. 2009. Available from: http://www.datasus.gov.br. Accessed in: 24 Mar. 2019. 
3. Kokkinos P. Physical Activity, Health Benefits, and Mortality Risk. ISRN Cardiol. 2012;2012:718789.

4. Warburton DER, Nicol CW, Bredin SSD. Health benefits of physical activity: the evidence. CMAJ. 2006;174(6):801-9.

5. Forjaz CLM, Bartholomeu T, Rezende JAS, Oliveira JA, Basso L, Tan G, et al. Desafios no estudo de famílias nucleares: etapas iniciais de análise. Rev Bras Educ Fís Esporte. 2011;25(4):717-30.

6. Burton PR, Tobin MD, Hopper JL. Key concepts in genetic epidemiology. Lancet. 2005;366(9489):941-51.

7. Maia JAR, Garganta R, Seabra A, Lopes VP. Heterogeneidade nos níveis de actividade física de crianças dos 6 aos 12 anos de idade: Um estudo em gémeos. Rev Port Ciênc Desporto. 2004;4(1): 39-50.

8. Fermino RC, Garganta R, Seabra A, Maia JAR. Efeitos genéticos e ambientais nos indicadores da composição corporal. uma revisão centrada em estudos de agregação familiar. Rev Bras Cineantropom Desempenho hum. 2007;9(4).

9. Trégouët DA, Herbeth $B$, Juhan-Vague I, Siest G, Ducimetière $P$, Tiret L. Bivariate familial correlation analysis of quantitative traits by use of estimating equations: Application to a familial analysis of the insulin resistance syndrome. Genet Epidemiol. 1999;16(1):69-83.

10. Tang W, Hong Y, Province MA, Rich SS, Hopkins PN, Arnett DK, et al. Familial Clustering for Features of the Metabolic Syndrome: The National Heart, Lung, and Blood Institute (NHLBI) Family Heart Study. Diabetes Care. 2006;29(3):631-6.

11. Santos DM, Katzmarzyk PT, Trégouet DA, Gomes TN, Santos FK, Maia JA. Familial Aggregation of Metabolic Syndrome Indicators in Portuguese Families. Biomed Res Int. 2013;2013:314823.

12. Mitchell BD, Rainwater DL, Hsueh WC, Kennedy AJ, Stern MP, Maccluer JW. Familial aggregation of nutrient intake and physical activity: results from the San Antonio Family Heart Study. Ann Epidemiol. 2003;13(2):128-35.

13. Maia J, Gomes TN, Trégouët DA, Katzmarzyk PT. Familial resemblance of physical activity levels in the Portuguese population. $J$ Sci Med Sport. 2014;17(4):381-6.

14. Sallis JF, PattersonTL, Buono MJ, Nader PR. Relation of Cardiovascular Fitness and Physical Activity to cardiovascular disease risk factors in children and adults. Am J Epidemiol. 1988;127(5):933-41.

15. Foraita R, Brandes M, Günther F, Bammann K, Pigeot I, Ahrens $W$. The influence of aerobic fitness on obesity and its parentoffspring correlations in a cross-sectional study among German families. BMC Public Health. 2015;15:638.

16. de Oliveira CM, Pereira AC, de Andrade M, Soler JM, Krieger JE. Heritability of cardiovascular risk factors in a Brazilian population: Baependi Heart Study. BMC Med Genet. 2008;9:32.

17. Wolfarth $B, B r a y$ MS, Hagberg JM, Pérusse L, Rauramaa R, Rivera $M A$, et al. The human gene map for performance and health-related fitness phenotypes: the 2004 update. Med Sci Sports Exerc. 2005;37(6):881-903.

18. Horimoto AR, Giolo SR, Oliveira CM, Alvim RO, Soler JP, de Andrade $M$, et al. Heritability of physical activity traits in Brazilian families: the Baependi Heart Study. BMC Med Genet. 2011;12:155.

19. Basso L, Meira Júnior C, Oliveira JA, Forjaz CLM, Souza JA, Prista $\mathrm{A}$, et al. Crescimento e desenvolvimento motor de escolares de Muzambinho: um estudo com implicações acadêmicas, sociais e de política interinstitucional. Rev Port Ciênc Desporto. 2009;9:247-57.

20. Forjaz CLM, Bartholomeu T, Rezende JAS, Oliveira JA, Basso L, Tani G, et al. Genetic and environmental influences on blood pressure and physical activity: a study of nuclear families from Muzambinho, Brazil. Braz J Med Biol Res.2012;45:1269-75.

21. IBGE - Instituto Brasileiro de Geografia e Estatística. Ministério da Educação, Instituto Nacional de Estudos e Pesquisas Educacionais (INEP) - Censo da Educação Superior. 2010.
22. Ministério da Saúde. Sistema de Informações sobre Mortalidade - SIM. 2016. Available from: http://www2.datasus.gov.br/DATASUS/index.php?area=060701. Accessed in: 24 Mar. 2019.

23. McCarthy HD, Jarrett KV, Crawley HF. The development of waist circumference percentiles in British children aged 5.0-16.9 y. Eur J Clin Nutr. 2001;55(10):902-7.

24. World Health Organization. Diet, Nutrition and the Prevention of Chronic Disease. Geneva: WHO; 2003.

25. Centers for Disease Control and Prevention (CDC). Growth Charts. 2000. Available from: http://www.cdc.gov/growthcharts. Accessed in: 24 Mar. 2019.

26. del Cañizo FJ, Froilán C, Moreira-Andrés MN. Precisión y exactitud de la medida del colesterol total mediante el reflectómetro Accutrend $\mathrm{GC} \circledast$. Aplicabilidad en atención primaria para la detección de hipercolesterolemias. Atención Primaria. 1996;17(7):463-6.

27. Thomas LE, Kane MP, Bakst G, Busch RS, Hamilton RA, Abelseth JM. A Glucose Meter Accuracy and Precision Comparison: The FreeStyle Flash Versus the Accu-Chek Advantage, Accu-Chek Compact Plus, Ascensia Contour, and the BD Logic. Diabetes Technol Ther. 2008;10(2):102-10.

28. Council of Europe Committee for the Development of Sport. EUROFIT: Hanbook for the EUROFIT tests of physical fitness. Roma; 1988.

29. Wigginton JE, Abecasis GR. Abecasis, PEDSTATS: descriptive statistics, graphics and quality assessment for gene mapping data. Bioinformatics. 2005;21(16):3445-7.

30. Bouchard C, Malina RM, Pérusse L. Genetics of fitness and physical performance. Champaign: Human Kinetics; 1997.

31. Biostatistics. Statistical Analysis for Genetic Epidemiology (SAGE). Available from: http://darwin.cwru.edu/sage/. Accessed in: 24 Mar. 2019.

32. Falconer DS, Mackay TF. Introduction to quantitative genetics. Harlow: Longman; 1996.

33. Mansour-Chemaly M, Haddy N, Siest G, Visvikis S. Family studies: their role in the evaluation of genetic cardiovascular risk factors. Clin Chem Lab Med. 2002;40(11):1085-96.

34. Elks CE, den Hoed M, Zhao JH, Sharp SJ, Wareham NJ, Loos RJ, et al. Variability in the heritability of body mass index: a systematic review and meta-regression. Front Endocrinol (Lausanne). 2012;3:29.

35. Reynolds CA, Baker LA, Pedersen NL. Models of spouse similarity: Applications to fluid ability measured in twins and their spouses. Behav Genet. 1996;26(2):73-88.

36. Santos DM, Katzmarzyk PT, Diego VP, Souza MC, Chaves RN, Blangero J, et al. Genotype by energy expenditure interaction with metabolic syndrome traits: the Portuguese healthy family study. PLoS One. 2013;8(11):e80417.

37. Maia JA, Thomis M, Beunen G. Genetic factors in physical activity levels. Am J Prevent Med. 2002;23(2):87-91.

38. Chaves RN, Souza MC, Santos D, Garganta R, Seabra A, Maia JAR. Agregação familiar nos níveis de atividade física: Um resumo do estado da arte. Rev Bras Ativ Fís Saúde. 2010;15(1):65-9.

39. de Chaves RN, Baxter-Jones A, Santos D, Gomes TN, dos Santos FK, de Souza MC, et al. Clustering of body composition, blood pressure and physical activity in Portuguese families. Ann Hum Biol. 2014;41(2):159-67.

40. Beunen G, Thomis M. Gene powered? Where to go from heritability (h2) in muscle strength and power? Exerc Sport Sci Rev. 2004;32(4):148-54.

41. Barbosa JP, Basso L, Seabra A, Prista A, Tani G, Maia JA, et al. Relationship between physical activity, physical fitness and multiple metabolic risk in youths from Muzambinho's study Eur J Sport Sci. 2016;16(5):618-23. 